COCOS (2007), 1858 - 66

Printed in Sri Lanka

\title{
EFFECT OF ABSCISIC ACID ON SURVIVAL AND RECOVERY OF CRYOPRESERVED PLUMULE EXPLANTS OF COCONUT (COCOS NUCIFERA L.)
}

\author{
H D D Bandupriya ${ }^{1}$, S C Fernando ${ }^{1}$, J-L Verdeil $^{2}$, B Malaurie $^{3}$ \\ ${ }^{1}$ Coconut Research Institute, Lunuwila, Sri Lanka; ${ }^{2}$ CIRAD, TA40/02 Avenue \\ Agropolis, 34398 Montpellier Cedex 5 - France; ${ }^{3} U M R 1098$ BEPC, \\ Institute for Research and Development (IRD), BP 64501, 911 Av Agropolis \\ 34394, Montpellier, France.
}

\begin{abstract}
ABSRACT
Cryopreservation has great potential for long-term storage of coconut genetic resources. The recent development of the encapsulation-dehydration cryogenic technique dramatically facilitated progress with cryopreservation. The present study tested the effect of abscisic acid in the encapsulationdehydration method for cryopreservation of coconut plumules. Plumules were excised from mature zygotic embryos of Coconut var. Sri Lanka Tall and encapsulated in calcium alginate. The alginate beads were used to test effect of different cryoprotection pretreatments (mixtures of $0.75 \mathrm{M}$ sucrose and abscisic acid (ABA) at concentrations of $0,10,20$ and $40 \mu \mathrm{M})$, and exposure to silica gel for 16 hours for further dehydration, prior to freezing in liquid nitrogen. Effect of the treatments without freezing was also tested. The water loss from alginate beads following sucrose incubation and dehydration was monitored, and the survival and growth of plumules assessed at different stages.

Addition of $\mathrm{ABA}$ to the sucrose pretreatment medium increased the survival rate of unfrozen plumules from $60 \%$ to over $80 \%$. Pretreatment with $40 \mu \mathrm{M}$ ABA gave the highest survival rate $(84 \%)$ of frozen plumules. The recovery rate of plumules (frozen and unfrozen) pretreated without ABA was very low $(6-8 \%)$. The addition of ABA increased the recovery rate significantly; frozen plumules that had been treated with $40 \mu \mathrm{M}$ ABA recorded a $39 \%$ recovery rate. The improved recovery could be ascribed to increased water loss $(69 \%)$ in plumules treated with $40 \mu \mathrm{M}$ ABA.
\end{abstract}

Key words: Coconut, plumule, cryopreservation, abscisic acid 


\section{INTRODUCTION}

The coconut palm (Cocos nucifera L.) is generally cultivated in the tropical regions both as large-scale plantations and in home gardens. The coconut palm yields a wide range of products and has been extensively cultivated over a long period of time. Consequently, many ecotypes have emerged through selection both by man and nature. Conservation of this genetic diversity is crucial for the development of future breeding programs before the ongoing genetic erosion takes its toll.

Coconut genetic resources are presently maintained ex-situ in the field at great cost and subject to adverse weather conditions, pests and diseases. Cryopreservation is an important alternative method for long-term conservation of coconut germplasm. Cryopreservation reduces cell and tissue deterioration by virtually halting metabolism when they are stored at ultra low temperatures, usually that of liquid nitrogen $\left(-196^{\circ} \mathrm{C}\right)$.

Coconut is propagated only by seeds. Coconut seed is recalcitrant in nature and large in size. Recalcitrant seeds cannot tolerate dehydration to moisture levels that would permit exposure to very low temperatures (Engelmann, 2000). This is no doubt a constraint to using cryopreservation for conserving coconut genetic resources.

Successful cryopreservation of mature zygotic embryos of coconut, using the pre-growth desiccation method, was reported by Assy-Bah and Engelmann (1992). However, only a few genotypes were tested. The large size of the embryo limits experimentation with other techniques such as those that require encapsulation. Coconut plumule i.e. the embryo meristem and first leaves, which is known to be free of viral diseases, is an interesting starting material for cryopreservation (Malaurie et al., 2002). Cryopreservation of plumules is vital because they are small in size (around $1.0 \mathrm{~mm}$ ) and abound in meristematic cells. Using the encapsulation-dehydration technique, coconut plumules have been successfully cryopreserved but the percentage recovery is low (N'Nan, 2004).

Artificial cryoprotection by incubation in sugar is generally required for recalcitrant species like coconut. Dehydration tolerance can be increased by adding abscisic acid (ABA) to the culture medium (Anandarajah and McKersie, 1990; Senaratna et al., 1991). ABA is also known to induce freezing tolerance in various species (Chen and Gusta, 1983). In the present study, the effect of ABA on the survival and recovery of coconut plumules, cryopreserved by the encapsulation-dehydration technique, was tested. 


\section{METHODOLOGY}

Mature zygotic embryos were extracted from 12 month-old seed nuts of the coconut variety Sri Lanka Tall. Plumules were excised from the embryos in a laminar airflow cabinet under a stereo microscope and precultured, for 4-7 days, in Eeuwens Y3 growth medium (Eeuwens, 1976). The precultured plumules were encapsulated in $3 \%(\mathrm{w} / \mathrm{v})$ sodium alginate and pretreated for three days in liquid Eeuwens medium, enriched with $0.75 \mathrm{M}$ sucrose and ABA (at concentrations of 10,20 and $40 \mu \mathrm{M}$ ), on a rotary shaker (90 rpm), at $27^{\circ} \mathrm{C}$ in the dark. After sucrose pretreatment, the beads were blotted on filter paper to remove surface moisture, weighed, and then dehydrated for 16 hours in glass jars with 20 plumules placed on top of $40 \mathrm{~g}$ silica gel separated by filter paper. The dehydrated beads were weighed, and half were transferred to sterile polypropylene cryotubes and directly plunged into liquid nitrogen. After at least 2 hours storage in liquid nitrogen,the tubes were warmed in a water bath at $40{ }^{\circ} \mathrm{C}$ for $3 \mathrm{~min}$. These frozen beads, and the unfrozen beads (subjected to pretreatment and dehydration only) were cultured in a recovery medium (Eeuwens Y3 growth medium).

Encapsulated plumules (without any pretreatment, dehydration or freezing) were also cultured in Eeuwens Y3 growth medium, soon after encapsulation, as an untreated control.

The survival of plumules was assessed after two months in culture. A plumule manifesting new tissue growth, indicated by any sign of regrowth such as swelling, development of new leaf primordia and/or callus formation, was counted as a survivor. The recovery of plumules was assessed after 4 months in culture. A plumule that grew and developed into a plantlet was counted as having recovered. The experimental design was a complete randomized design with three replicates, and 10 plumules per treatment. Arcsine transformed data was analysed using the GLM procedure (SAS Institute, USA)

\section{RESULTS AND DISCUSSION}

A critical parameter in cryopreservation is the removal of intracellular water, to prevent ice crystals forming during freezing or thawing and consequent cell damage (Fang et al, 2004). This necessitates the pretreatment of encapsulated plumules with cryoprotectants such as sugars, sugar alcohols, DMSO etc. 
Irrespective of ABA treatments, all the plumules that were not subjected to dehydration and cryostorage survived and developed into normal plantlets; and none of the plumules not subjected to dehydration, survived cryostorage (Table 1 and 2). The survival rate of dehydrated but unfrozen plumules varied from $60 \%$ to $84 \%$. Very high survival rates $(>80 \%)$ were observed in dehydrated, unfrozen plumules pretreated with 10-40 $\mu \mathrm{M}$ ABA, clearly indicating the positive effect of ABA on their survival. Similarly, pretreatment with $\mathrm{ABA}$ increased the survival rate of dehydrated, frozen plumules from $57 \%$ without $\mathrm{ABA}$ to $84 \%$ with $40 \mu \mathrm{M}$ ABA.

With both frozen and unfrozen, dehydrated embryos, the positive effect of ABA on recovery was quite clear. When they were pretreated only with sucrose (zero ABA) the recovery rate was very low but increased remarkably when ABA was added to sucrose (Table 2). Frozen plumules recorded the highest rate of recovery (39\%) when pretreated with sucrose containing ABA at a concentration of $40 \mu \mathrm{M}$.

Table 1: Effect of ABA concentration on survival of encapsulated plumules following dehydration and cryopreservation

\section{Treatment}

Dehydration in hours

\begin{tabular}{lllll}
\cline { 2 - 5 } $\begin{array}{l}\text { Sucrose } \\
(\mu \mathrm{M})\end{array}$ & \multicolumn{2}{c}{ No } & \multicolumn{1}{c}{$\begin{array}{c}\text { Dehydration for } 16 \\
\text { hours }\end{array}$} \\
& dehydration & & \\
\cline { 2 - 5 } & -LN & $+\mathrm{LN}$ & $-\mathrm{LN}$ & $+\mathrm{LN}$ \\
\hline $0.75+0$ & $100 \pm 0$ & $0 \pm 0$ & $60 \pm 12$ & $57 \pm 14$ \\
$0.75+10$ & $100 \pm 0$ & $0 \pm 0$ & $82 \pm 6$ & $68 \pm 15$ \\
$0.75+20$ & $100 \pm 0$ & $0 \pm 0$ & $85 \pm 8$ & $39 \pm 20$ \\
$0.75+40$ & $100 \pm 0$ & $0 \pm 0$ & $84 \pm 8$ & $84 \pm 5$ \\
\hline
\end{tabular}

Values represent survival percentage $\pm \mathrm{SE}$.

$\mathrm{P}$ (survival) $<0.0001$; treatment differences were evaluated at 5\% probability.

LN:liquid nitrogen

In this experiment, dehydration of plumules was initially by the sucrose pretreatment and then by exposure to silica gel for 16 hours. Water loss in plumules was lowest (62\%, fresh weight basis) when pretreated with $0.75 \mathrm{M}$ sucrose without $\mathrm{ABA}$, and highest (69\%, fresh weight basis) when pretreated 
with $0.75 \mathrm{M}$ sucrose containing $\mathrm{ABA}$ at a concentration of $40 \mu \mathrm{M}$. The increase in recovery rate of plumules with the latter pretreatment appears to be a result of increased dehydration.

The influence of ABA and sugars on the tolerance of tissues to dehydration and cryopreservation has received much attention (Dumet et al., 1993; Nieves et al., 2001). Sucrose infiltrating into tissues helps to maintain their viability during dehydration and cryopreservation by stabilizing cell membranes. Sucrose, by replacing water, maintains membrane phospholipids in the liquid crystalline phase (Hoekstra et al., 1991), and prevents structural changes in soluble proteins (Carpenter et al., 1987). Sucrose, due to its solute properties, also promotes glass phase formation in the cytoplasm (Koster, 1991). ABA plays an important role in desiccation tolerance of several plant species (Senaratna et al., 1989; Shiota et al., 1999). ABA is associated with synthesis of proteins (Seijo, 2000) and compatible solute components, which are important in plant stress tolerance (Fang et al., 2004). A combination of ABA and sucrose treatments improved the survival of cryopreserved cocoa somatic embryos (Fang et al., 2004).

Table 2: Effect of ABA concentration on recovery of encapsulated plumules following dehydration and cryopreservation

Treatment

Dehydration in hours

\begin{tabular}{|c|c|c|c|c|}
\hline \multirow[t]{2}{*}{$\begin{array}{c}\text { Sucrose }(\mathrm{M})+\mathrm{ABA} \\
(\mu \mathrm{M})\end{array}$} & \multicolumn{2}{|c|}{ No dehydration } & \multicolumn{2}{|c|}{$\begin{array}{c}\text { Dehydration for } 16 \\
\text { hours }\end{array}$} \\
\hline & $-\mathrm{LN}$ & $+\mathrm{LN}$ & -LN & $+\mathrm{LN}$ \\
\hline $0.75+0$ & $93 \pm 4$ & $0 \pm 0$ & $6 \pm 6$ & $8 \pm 4$ \\
\hline $0.75+10$ & $100 \pm 0$ & $0 \pm 0$ & $45 \pm 15$ & $17 \pm 9$ \\
\hline $0.75+20$ & $100 \pm 0$ & $0 \pm 0$ & $43 \pm 2$ & $23 \pm 12$ \\
\hline $0.75+40$ & $100 \pm 0$ & $0 \pm 0$ & $45 \pm 9$ & $39 \pm 6$ \\
\hline
\end{tabular}

Values represent recovery percentage $\pm \mathrm{SE}$.

$\mathrm{P}$ (recovery) < 0.0001; treatment difference were evaluated at 5\% probability.

LN:liquid nitrogen 
Table 3: Mean percent water loss from plumules pretreated in sucrose and dehydrated with silica gel.

\begin{tabular}{lcccc}
\hline $\begin{array}{l}\text { Concentration of ABA }(\mu \mathrm{M}) \text { in } \\
\text { the sucrose solution }\end{array}$ & 0 & 10 & 20 & 40 \\
\hline $\begin{array}{l}\text { Mean percentage of water loss } \\
\text { (fresh weight basis) }\end{array}$ & 62 & 67 & 68 & 69 \\
\hline
\end{tabular}

N'Nan (2004) and Malaurie et al. (2002) using the encapsulationdehydration method with different sucrose concentrations and dehydration periods, achieved about $40-70 \%$ survival and about $20 \%$ recovery of coconut plumules after cryopreservation. In the present study, the optimum sucrose concentration and dehydration duration reported by N'Nan (2004) were used to investigate the influence of $\mathrm{ABA}$ on the survival and recovery of cryopreserved plumules. The preliminary results are encouraging and indicates the feasibility of using ABA for effective cryopreservation of coconut germplasm. It is likely that the recovery rate could be further improved by refining the protocol.

\section{ACKNOWLEDGEMENT}

Authors gratefully acknowledge the financial assistance provided by the IRD, through a research project funded by Bureau des Ressources Genetiques, Paris, France (BRG). Thanks are also due to all staff members of Lab Genetrop, IRD, France and Tissue Culture Division, CRI, Sri Lanka for their assistance in carrying out the experiments. We acknowledge the valuable comments of Dr L K Weerakoon, Head Tissue Culture Division on the manuscript. Thanks are also extended to Dr. T S G Peiris and Mr. J.D.J.S. Kularathne of the Biometry Division, CRI for their assistance in the statistical analysis of data. 


\section{REFERENCES}

Anandarajah, K. and McKersie, B. D. (1990). Manipulating the desiccation tolerance and vigor of dry somatic embryos of Medicago sativa L. with sucrose, heat shock and abscisic acid, Plant Cell Reports 9:451455.

Assy-Bah and Engelmann, F. (1992). Cryopreservation of mature embryos of coconut (Cocos nucifera L.) and subsequent regeneration of plantlets, Cryo-letters 13,117-126.

Blake, J. (1995). A brief history of coconut tissue culture, In: Oropeza, V., Howard, F. W., and Ashburner, G. R., (eds.) Lethal yellowing: research and practical aspects. Dordrecht, The Netherlands: Kluwer Academic Publishers, 217-223.

Carpenter, J. F., Crowe, L. M. and Crowe, J. H. (1987). Stabilization of phosphofructokinase with sugars during freeze-drying: characterization of enhanced protection in the presence of divalent cations, Biochim. Biophys. Acta 923:109-115.

Chen, T. H. H. and Gusta, L. V. (1983). Abscisic acid induced freezing tolerance in cultured plant cells, Plant Physiology 73: 71-75

Dumet, D., Engelmann, F., Chabrillange, N., Duval,Y. and Dereuddre, J. (1993). Importance of sucrose for the acquisition of tolerance to desiccation and cryopreservation of oil palm somatic embryos, CryoLetters 14:243-250

Eeuwens, C. J. (1976). Mineral requirements for growth and callus initiation of tissue explants excised from mature coconut palm (Cocos nucifera) and cultured in vitro, Physiol. Plant. 36:23-28

Engelmann, F. (2000). Importance of cryopreservation for the conservation of palnt genetic resources, In: Engelmann, F. and Takagi, (eds.) Cryopreservation of tropical plant germplasm. Current research progress and application, Japan International Center for Agricultural Sciences, Japan and International Plant Genetic Resources Institute; Rome, Italy, 8-20 
Fang, J. Y., Wetten, A. and Hadley, P. (2004). Cryopreservation of cocoa (Theobroma cocoa L.) somatic embryos for long term germplasm storage, Plant Science 166:669-675.

Hoekstra, F.A., Crowe, J.H. and Crowe, L.M. (1991). Effect of sucrose on phase behaviour of membranes in intact pollen of Typha latifolia $\mathrm{L}$. as measured with Fourier transform infrared spectroscopy, Plant Physiol. 97:1073-1079.

Koster, K.L. (1991). Glass formation and desiccation tolerance in seeds, Plant Physiol. 96:302-304.

Malaurie B., N' Nan, O., Hocher, V., Ilbert, P., Grosdemang, F., Konan, JL., Zakra, N. and Verdeil, J-L. (2002). State of zygotic coconut embryo culture and cryopreservation research at IRD/CIRAD (France), Coconut embryo in vitro culture part $\Pi, 146-156$.

N'Nan, O. (2004). Utilisation des biotechnologies comme seconde voie pour les echanges et la conservation des ressources genetiques du cocotier (Cocos nucifera L.), PhD thesis, Angers University.

Nieves, N., Martinez, M. E., Catillo, R., Blanco, M. A. and GonzalezOlmedo, J. L. (2001). Effect of abscisic acid and jasmonic acid on partial desiccation of encapsulated somatic embryos of sugarcane, Plant Cell Tissue and Organ Culture 65:15-21

Roberston, A.J., Ishikawa, M. and Gusta, L.V. (1995). The effect of prolonged abscisic acid treatment on the growth, freezing tolerance and protein patterns of Bromus inermis (Leyss) cell suspensions cultured at either $3^{\circ}$ or $25^{\circ} \mathrm{C}$, J. Plant Physiology 145:137-142

Seijo, G. (2000). Effect of preculture with sucrose and ABA on cell suspension water status and its relation with vitrification resistance, R. Bras.Fisiol Veg, 12 (2):166-180.

Senaratna T., Kott, L., Beversdorf, W. D. and McKersie, B. D. (1991). Desiccation of microspore derived embryos of oilseed rape (Brassica napus L.), Plant Cell Reports 10:342-344 
Senaratna, T., McKersie, B.D. and Bowley, S.R. (1989). Desiccation tolerance of alfalfa (Medicago sativa L.) somatic embryos. Influence of abscisic acid, stress pretreatments and drying rates, Plant Sci. 65:253-259.

Shiota, H., Tachibana, K., Watabe, K. and Kamada, H. (1999). Successful long term preservation of abscisic acid-treated and desiccated carrot somatic embryos, Plant Cell reports 18:749-753. 